\title{
Pengelolaan Diabetes Insipidus dengan Cerebral Salt Wasting Syndrome dan Tension Pneumocephalus pada Pasien Pascabedah Eksisi Tumor Pineal
}

\author{
Dhania A. Santosa, Nancy Margarita Rehatta \\ Departemen Anestesiologi dan Reanimasi Fakultas Kedokteran Universitas Airlangga- RSUD Dr. Soetomo \\ Surabaya
}

\begin{abstract}
Abstrak
Ketidakseimbangan elektrolit pada pasien pasca bedah saraf sering terjadi dan berpotensi menyebabkan cedera otak sekunder yang dapat memperburuk luaran pasien, sekalipun pembedahan sukses dilaksanakan. Diabetes insipidus merupakan disfungsi hipofisis yang menyebabkan hipernatremia. Kondisis ini sering terjadi pada kelainan hipofisis, namun jarang sebagai akibat tumor pineal. Seorang pasien laki-laki usia 21 tahun dengan diabetes insipidus prabedah menjalani pembedahan kraniotomi dan eksisi tumor pineal. Pada periode pascabedah pasien mengalami episode diabetes insipidus yang dipersulit dengan Cerebral Salt Wasting Syndrome dan Tension Pneumocephalus. Pemantauan ketat akan status volume, kadar gula dan elektrolit darah serta dosis desmopressin yang optimal merupakan kunci keberhasilan penanganan pasien ini sehingga tidak mengalami cedera otak sekunder. Seorang intensivis memegang peranan penting dalam pengelolaan pasien seperti ini terutama terkait patofisiologi kelainan intrakranial dan implikasinya terhadap keseimbangan cairan dan elektrolit.
\end{abstract}

Kata kunci: pascabedah eksisi tumor pineal, diabetes insipidus, cerebral salt wasting syndrome, tension pneumocephalus

JNI 2021; 10 (3): 182-92

\section{Management of Diabetes Insipidus Complicated by Cerebral Salt Wasting Syndrome and Postoperative Tension Pneumocephalus in a patient who underwent Pineal Tumor Removal}

\begin{abstract}
Electrolyte imbalance is an often incident in patients underwent neurosurgery and it potentially induces secondary brain injury, leading to a worse outcome, despite successful surgery. Diabetes insipidus is a frequent hypernatremic condition, commonly caused by abnormalities in the hypophysis; but rarely happens due to pineal tumor. A 21-year-old male with preoperative diabetes insipidus experienced episodes of diabetes insipidus complicated by cerebral salt wasting syndrome and tension pneumocephalus after a successful pineal tumor removal surgery. Closed observation on volume status, plasma glucose and electrolyte, along with optimal dose of desmopressin were keys of successful postoperative management in this patient in order to avoid the patient from secondary brain injury. An intensivist plays a key role, mainly in the understanding of intracranial pathophysiology and its implications to fluid and electrolyte balance.
\end{abstract}

Key words: postoperative pineal tumor removal, diabetes insipidus, cerebral salt wasting syndrome, tension pneumocephalus

JNI 2021; 10 (3): 182-92

This article is licensed under

Creative Commons Attribution-NonCommercial-ShareAlike 4.0 International License.

CDhania A. Santosa, Nancy Margaritta R

(2021) under the CC-BY-NC-SA license 


\section{Pendahuluan}

Susunan saraf pusat (SSP) berperan penting dalam regulasi homeostasis kadar air dan natrium dalam darah. Oleh karenanya, pasien dengan proses neurologis maupun pascabedah otak sangat mungkin mengalami ketidakseimbangan cairan dan elektrolit. ${ }^{1}$ Selain karena proses intrakranial, kelainan elektrolit ini dapat pula disebabkan karena banyak faktor di antaranya tindakan pembedahan atau iatrogenic, tindakan perawatan pascabedah di intensive care unit (ICU), akibat pemberian cairan infus maupun obat-batan. ${ }^{2}$ Kelainan elektrolit yang sering terjadi pada pasien bedah saraf adalah hiponatremia, dengan tingkat kejadian sekitar $10-50 \% .^{2}$ Kondisi ini biasanya terjadi pada kasus subarachnoid hemorrhage (SAH), cedera otak traumatik (COT) dan pembedahan tumor hipofise. ${ }^{2}$ Kelainan kadar natrium dalam darah ini mungkin akan sulit dibedakan secara klinis karena gejala dan tanda yang muncul mungkin mirip satu dengan lainnya meskipun mempunyai patofisiologi yang berbeda.

Di antara kelainan hiponatremia yang banyak terjadi, $62 \%$ pasien mengalami hiponatremia yang disebabkan karena syndrome of inappropriate antidiuretic hormone (SIADH) dan sebagian kecil $(16,6 \%)$ disebabkan karena cerebral salt wasting syndrome (CSWS). ${ }^{3}$ Sedangkan kasus hipernatremia paling sering terjadi disebabkan oleh diabetes insipidus (DI). Diabetes insipidus sering terjadi pada fase akut pascabedah saraf, terutama bila pembedahan di daerah hipofise. Diabetes insipidus terjadi pada sekitar 3,8\% pasien bedah saraf, di mana sering dikaitkan dengan SAH, COT dan intracerebral hemorrhage (ICH). ${ }^{2}$ Pada diabetes insipidus terjadi poliuri (produksi urine lebih dari 4-8 liter per hari) di mana yang keluar adalah free water, sehingga bila tidak dilakukan penggantian cairan dengan baik maka akan dapat terjadi hipernatremia yang berbahaya dan dapat menyebabkan cedera otak sekunder.

Dalam laporan kasus ini dipaparkan DI yang kemungkinan sudah terjadi sejak fase pra bedah tumor pineal. Hal ini jarang terjadi karena letak tumor pineal yang tidak berdekatan dengan hipofise. Kasus ini menjadi makin kompleks ketika dalam pemeriksaan lanjutan pascabedah didapatkan natriuresis yang merupakan tanda terjadinya CSWS secara bersamaan. Terjadinya CSWS ini kemungkinan besar terkait dengan terjadinya tension pneumocephalus pasca bedah yang dapat berhubungan dengan faktor circulating natriuretic peptide atau penurunan sympathetic input pada ginjal, maupun keduanya. ${ }^{2}$ Dalam penanganan pasien dengan DI bersama CSWS ini diperlukan pemahaman patofisiologi yang cukup rumit akan kelainan elektrolit pada gangguan SSP sekaligus strategi penggantian cairan serta pemantauan kadar gula darah dan elektrolit pasien.

\section{Kasus}

Seorang laki-laki berusia 21 tahun, berat badan $72 \mathrm{~kg}$, tinggi badan $168 \mathrm{~cm}$ pasca bedah kraniotomi eksisi tumor pineal dan pemasangan external ventricular drainage. Pada pemeriksaan pra bedah pasien dinilai sebagai PS ASA 3 dengan penyulit: proses intrakranial, peningkatan fungsi hepar (SGPT 57, SGOT 137), hypernatremia $(154 \mathrm{mEq} / \mathrm{L})$ dan penurunan kesadaran (GCS E4V3M4). Teknik anestesi yang dikerjakan adalah anestesi umum dengan intubasi endotrakea. Anestesi berlangsung selama 6 jam sedangkan pembedahan berlangsung selama 4 jam. Kondisi pasien selama pembedahan stabil dengan perdarahan sebanyak $250 \mathrm{~mL}$. Pada kasus ini diperlukan perhatian khusus selama anestesi pembedahan adalah produksi urine sebanyak $1.110 \mathrm{~mL}$ dalam 6 jam atau setara dengan $185 \mathrm{~mL} /$ jam atau 2,6 mL/kg/jam. Pada akhir pembedahan, pasien dilakukan ekstubasi di kamar operasi dan diobservasi di Intensive Care Unit (ICU).

\section{Pemeriksaan Fisik}

Pada saat tiba di ICU didapatkan kondisi jalan napas bebas, dengan pernapasan spontan 16 kali per menit, gerak dada simetris, suara napas vesikuler kanan dan kiri, tidak terdapat suara napas tambahan. Pulse oximetry terbaca 98\% dengan udara bebas $\left(\mathrm{FiO}_{2} 21 \%\right)$. Pada perabaan didapatkan perfusi hangat, kering dan merah, 
dengan capillary refill time kurang dari 2 detik. Tekanan darah 103/52 dan MAP $69 \mathrm{mmHg}$ dan nadi 62 kali per menit, nadi radialis teraba teratur dan kuat angkat. Pasien masih dalam pengaruh anestesi dan dalam perjalanannya didapatkan GCS E4V4M6. Produksi urine 1 jam terakhir 120 $\mathrm{mL}$ via kateter.

\section{Pemeriksaan Penunjang:}

Pemeriksaan laboratorium pascabedah didapatkan hasil Hemoglobin 16,0 g/dL, hematokrit 49\%, leukosit $17.730 / \mathrm{mm} 3$, trombosit $341.000 \mu \mathrm{L}$. albumin $3,7 \mathrm{~g} / \mathrm{dL}$, natrium $169 \mathrm{mEq} / \mathrm{L}$, kalium $3,7 \mathrm{mEq} / \mathrm{L}$, chlorida $125 \mathrm{mEq} / \mathrm{L}$, gula darah acak $99 \mathrm{mg} / \mathrm{dL}$. Analisa gas darah pasien didapatkan
pH 7,295; $\mathrm{pCO}_{2} 35,6 ; \mathrm{pO}_{2}$ 138,4; $\mathrm{HCO}_{3}$ 17,5, BE -7,6. Dari pemeriksaan CT scan pascabedah didapatkan hasil tidak ada sisa tumor maupun perdarahan, namun didapatkan Mt Fuji sign yang menandakan tension pneumocephalus pada regio frontal namun tidak ada rencana dilakukan tindakan apa pun.

Pengelolaan di ICU

Pada hari pertama pascabedah pasien diberikan cairan intravena ringerfundin sebanyak 2000 $\mathrm{mL} / 24$ jam, injeksi parecoxib $40 \mathrm{mg}$ iv tiap 12 jam selama 2 hari, inj ondansetron $8 \mathrm{mg}$ iv tiap 12 jam selama 1 hari, inj pantoprazole $40 \mathrm{mg}$ iv tiap 12 jam selama1 hari dan dexmedetomidine

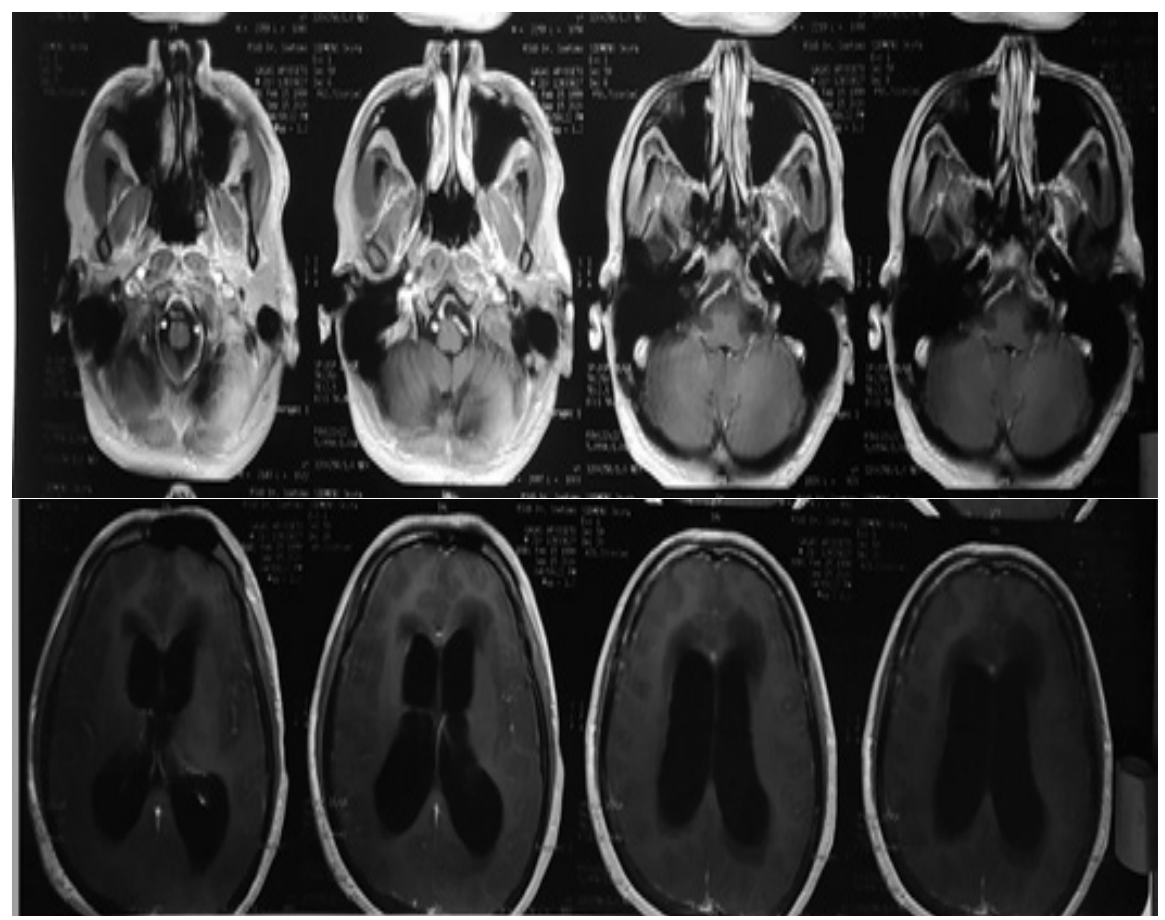

Gambar 2. MRI Kepala Pasien Prabedah

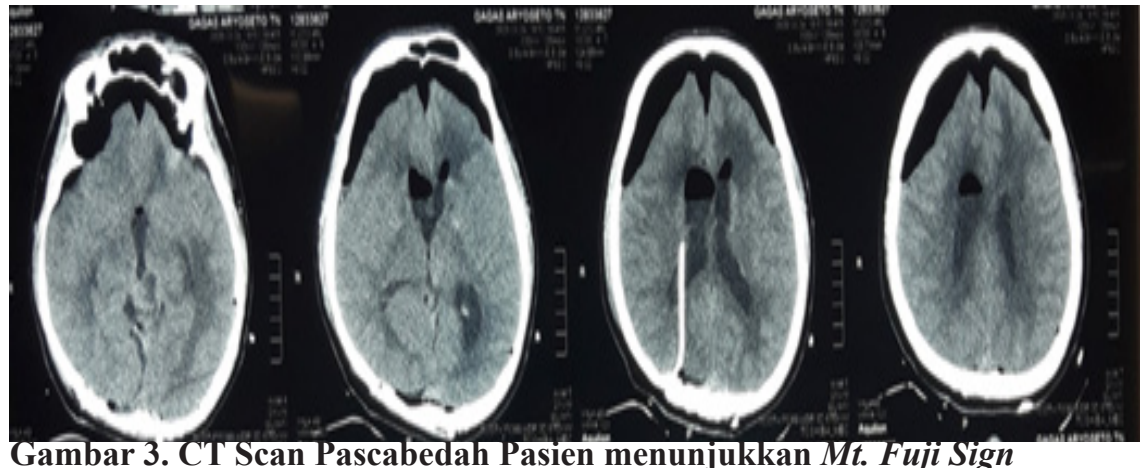

Gambar 3. CT Scan Pascabedah Pasien menunjukkan Mt. Fuji Sign

Menandakan adanya Tension Pneumocephalus 
0,2-0,4 $\mathrm{mcg} / \mathrm{kg} / \mathrm{jam}$ sampai dengan keesokan harinya. Selain kondisi klinis tanda vital, hal yang menjadi perhatian khusus pasien selama dirawat di ICU adalah tren produksi urine yang banyak dan hasil pemeriksaan serum elektrolit, dalam hal ini kadar natrium yang cenderung tinggi.

Setelah didapatkan hasil laboratorium kadar natrium dalam plasma yaitu $169 \mathrm{mEq} / \mathrm{L}$ dan kadar klorida $125 \mathrm{mEq} / \mathrm{L}$ dan produksi urine 270 $\mathrm{mL} / 2$ jam (setara $1,9 \mathrm{~mL} / \mathrm{kg} / \mathrm{jam}$ ) maka strategi terapi pasien diubah menjadi: infus D5 0,225 NS $2000 \mathrm{~mL} / 24$ jam, keseimbangan cairan dilakukan tiap 3 jam dengan target keseimbangan cairan maksimal defisit 750-1000 mL. Produksi urine yang berlebih digantikan dengan minum air putih bebas tercatat ditambah dengan D5 melalui infus. Kadar gula darah dipantau tiap 3 jam sedangkan serum elektrolit tiap 6 jam. Selain itu dibeirkan minirin (desmopressin) $0,1 \mathrm{mg}$ per oral tiap 8 jam serta injeksi furosemide $20 \mathrm{mg}$ intravena tiap 8 jam untuk mengeluarkan kadar klorida yang tinggi.

Kondisi pasien pada hari pertama pascabedah: pasien bernapas spontan 21 kali per menit $\mathrm{SpO}_{2} 97 \%$ dengan udara bebas. Perfusi hangat kering merah dengan tekanan darah 117/57 (75) $\mathrm{mmHg}$ dan nadi 86 kali per menit. Kesadaran GCS 456 dengan produksi urine 3 jam terakhir berkisar 80-100 mL/jam. Keseimbangan cairan total ekses $360 \mathrm{~mL}$. Pasien tetap diobservasi kesadaran, tanda vital, keseimbangan cairan dan produksi urine. Pasien diperiksa gula darah tiap 3 jam, analisa gas darah dan serum elektrolit tiap 6 jam. Pada hari pertama pasien diberikan cairan rumatan ringerfundin $2000 \mathrm{~mL} / 24 \mathrm{jam}$. Keseimbangan cairan ditargetkan defisit $750 \mathrm{~mL}$, di mana produksi urine yang berlebih digantikan dengan minum bebas tercatat dan pemberian D4 melalui infus. Koreksi kalium juga diberikan. Selain obat-obatan yang diberikan pada hari ke0 , ditambahkan phenytoin $100 \mathrm{mg}$ tiap 8 jam iv, dexamethasone $5 \mathrm{mg}$ tiap 8 jam iv, asam traneksamat $500 \mathrm{mg}$ tiap 8 jam iv dan furosemide $20 \mathrm{mg}$ iv tiap 8 jam sedangkan minirin $0,1 \mathrm{mg}$ per oral tiap 8 jam dihentikan. Produksi urine selama hari pertama pascabedah ini berfluktuasi menjadi sekitar 200-800 $\mathrm{ml} /$ jam pada 1-2 jam pasca

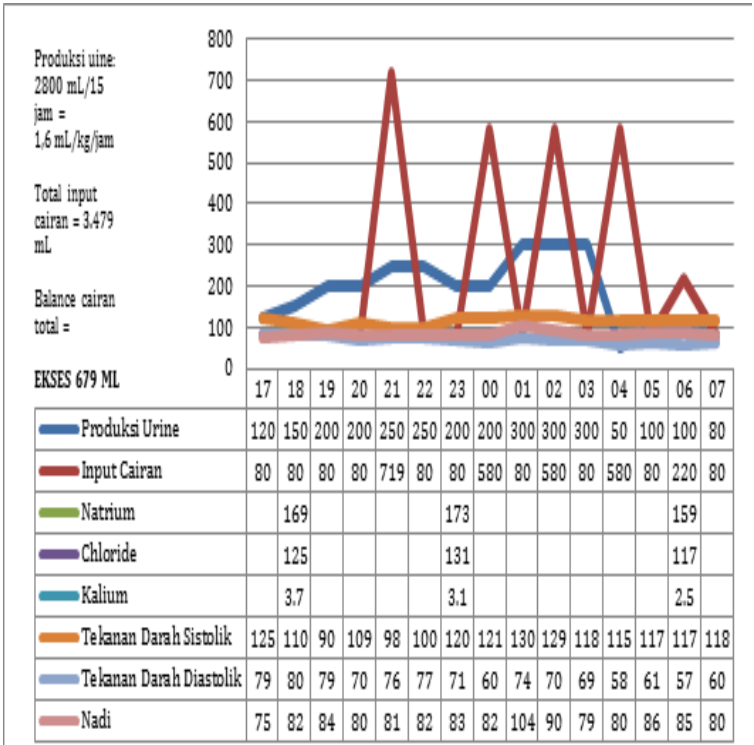

Grafik 1. Produksi Urine, Pemeriksaan Serum Elektrolit dan Gula Darah Pasien pada hari ke-0 Pascabedah

pemberian furosemide kemudian berkurang menjadi 40-100 $\mathrm{ml} /$ jam pada jam ketiga dan seterusnya. Selain minum per oral, pada hari pertama ini pasien mulai dapat makan bubur halus rendah garam. Pada hari kedua pasca bedah kondisi pasien bernapas spontan 18 kali per menit dengan $\mathrm{SpO}_{2}$ 98\% dengan udara bebas. Tekanan darah 118/70 (86) mmHg, nadi 79 kali per menit. Keseimbangan cairan total ekses $630 \mathrm{~mL}$. Untuk hari kedua ini pasien direncakan diberikan infus

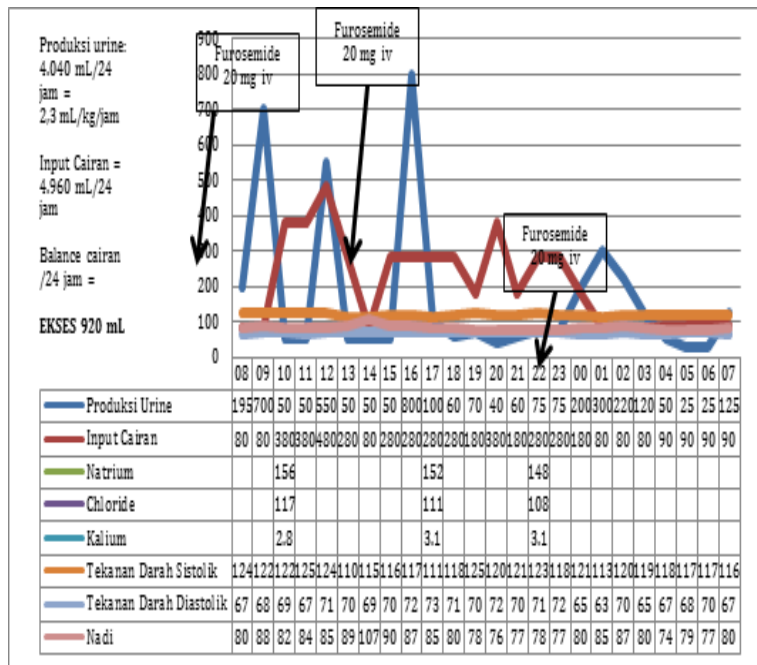

Grafik 2. Kondisi Pasien hari Pertama

Pascabedah 


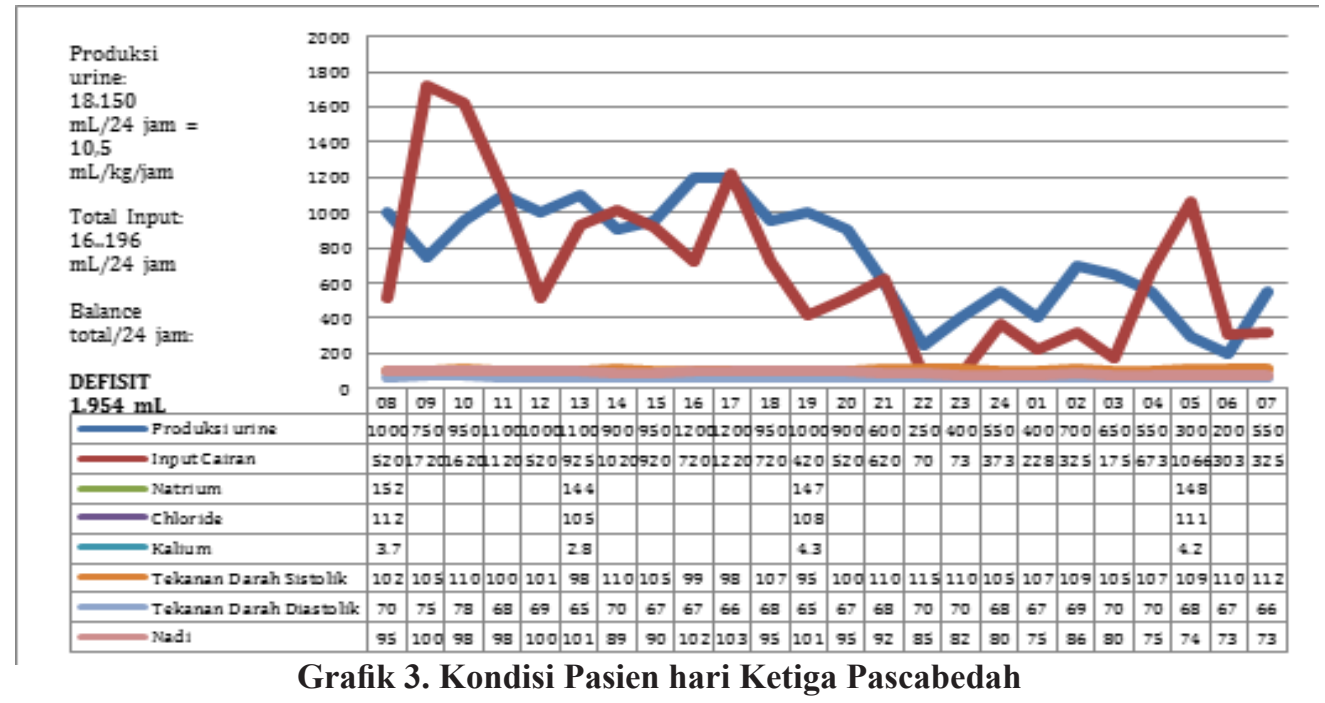

Ringerfundin $1000 \mathrm{~mL} / 24$ jam, minum bebas tercatat dan diet rendah garam. Selain itu pasien mendapatkan injeksi phenytoin $100 \mathrm{mg}$ intravena tiap 8 jam, inj dexamethasone $5 \mathrm{mg}$ intravena tiap 8 jam serta furosemide $20 \mathrm{mg}$ intravena tiap 8 jam. Pasien direncanakan untuk dipindah ke intermediate/low care.

Pada hari kedua pascabedah sore hari ini, pasien cenderung mengantuk, namun dapat dibangunkan untuk minum air. Produksi urin cenderung meningkat sebesar $2800 \mathrm{~mL}$ dalam 10 jam (setara dengan $3,9 \mathrm{~mL} / \mathrm{kg} / \mathrm{jam}$ ) sehingga diputuskan pasien tetap dirawat di ICU dan furosemide dihentikan. Pasien juga diberikan infus ringerfundin $2000 \mathrm{~mL} / 24$ jam untuk rumatan, mengantisipasi kondisi pasien yang mengantuk. Pada sore hari ini pula didapatkan hasil pemeriksaan elektrolit urine dari urine tampung 24 jam sebelumnya, yaitu: natrium 464,2 (normal 30-300), kalium 52,2 (normal 3580 ), chlorida 530,6 (normal 85-170). Pada saat ini pasien dicurigai juga mengalami cerebral salt wasting syndrome (CSWS) selain DI. Pada hari ketiga pascabedah didapatkan pasien bernapas spontan dengan RR 18 kali per menit, $\mathrm{SpO}_{2}$ 9899\% dengan udara bebas. Tekanan darah 118/70 (83) $\mathrm{mmHg}$, nadi 79 kali per menit. Pasien sadar

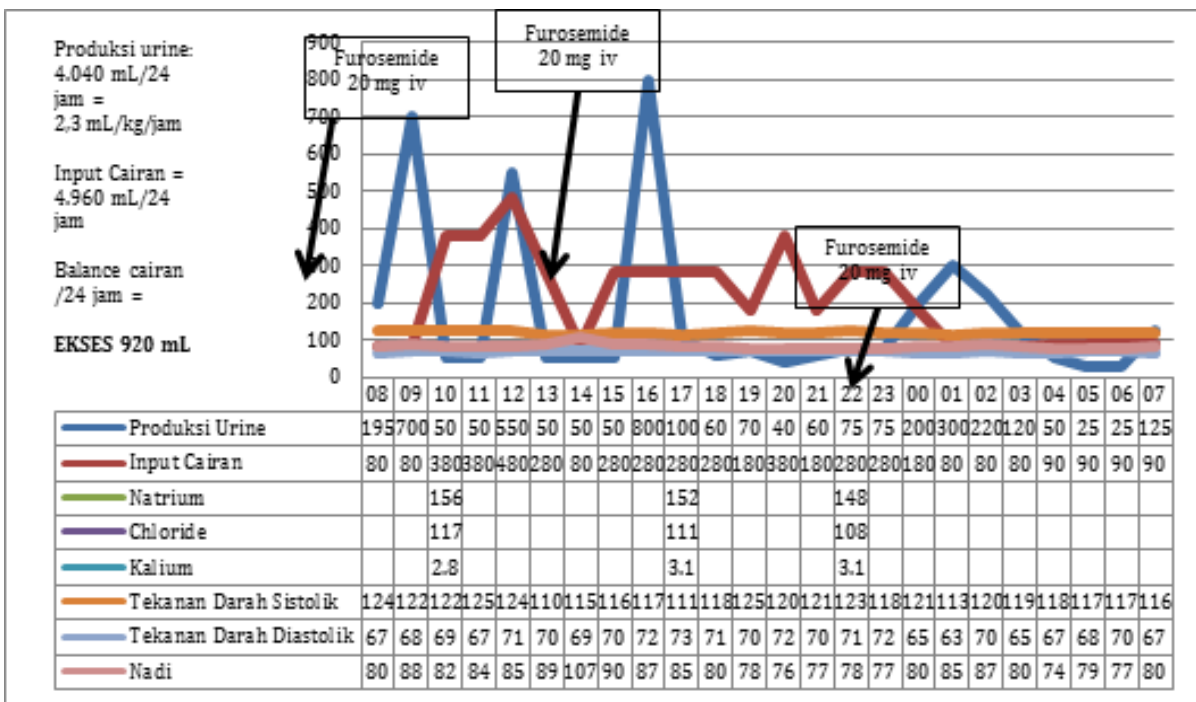

Grafik 4. Kondisi Pasien hari Kedua Pascabedah 
baik, GCS E4V5M6 dengan produksi urine dalam 24 jam sebelumnya $9.500 \mathrm{~mL}$, setara dengan $5,5 \mathrm{~mL} / \mathrm{kg} / \mathrm{jam}$ dengan keseimbangan cairan kumulatif hari sebelumnya defisit $1615 \mathrm{~mL}$. Pasien minum air putih bebas tercatat, selain itu diberikan D5 melalui infus dan ringerfundin 500 $\mathrm{mL} / 24$ jam. Pada awal hari ketiga pascabedah ini didapatkan kadar natrium dan chloride yang semakin meningkat dengan berat jenis urine yang dibawah normal $(1,002)$. Seiring berjalannya waktu pada hari ketiga ini produksi urine semakin banyak mencapai $5300 \mathrm{~mL}$ dalam 6 jam pertama hari ketiga (setara dengan 12,3 $\mathrm{mL} / \mathrm{kg} / \mathrm{jam}$ ) sehingga di titik ini dimulai kembali terapi minirin (desmopressin) $0,1 \mathrm{mg}$ tiap 8 jam per oral dengan terus memantau produksi urine, kadar natrium dan gula dalam plasma, dengan target defisit maksimal 750-1000 mL. Seiring berjalannya waktu, target keseimbangan cairan ini bergeser menjadi defisit maksimal 1500-2000 $\mathrm{mL}$ di mana pada akhir hari ketiga produksi urine dapat menurun kembali menjadi $1050 \mathrm{~mL} / 3$ jam terakhir (setara dengan $4,9 \mathrm{~mL} / \mathrm{kg} / \mathrm{jam}$ ).

Pada hari ketiga pascabedah inilah tampaknya puncak terjadinya DI pada pasien dengan total jumlah produksi urine $18.150 \mathrm{~mL}$ dalam 24 jam (setara dengan 10,5 mL/kg/jam) dengan keseimbangan cairan total defisit $1954 \mathrm{~mL}$. Kondisi pasien pascabedah hari ke-4 sebagai berikut: pasien bernapas spontan RR 18 kali per menit dengan $\mathrm{SpO}_{2}$ 98-99\% dengan udara bebas.
Tekanan darah 111/77 (83) mmHg, nadi 98 kali per menit. Kesadaran GCS E4V5M6, produksi urine 3 jam terakhir berkisar 200-550 mL/24 jam. Pasien diberikan minirin sesuai jadwal, selain itu dilakukan pemantauan keseimbangan cairan tiap jam dengan target defisit maksimal sampai dengan $2000 \mathrm{~mL}$. Pada hari ke-4 ini awalnya produksi urine masih banyak sampai dengan tertinggi $880 \mathrm{~mL} /$ jam selama 12 jam pertama. Pada saat ini masih dipikirkan adanya kemungkinan cerebral salt wasting syndrome (CSWS) atas dasar efektivitas minirin yang tampaknya tidak sebaik pada waktu terjadi diabetes insipidus pada hari ke-0 pascabedah dan hasil elektrolit dalam urine sebagai berikut: natrium 381,57 (normal 30-300), chloride 508,76 (normal 85-170) dan kalium 38,16 (normal 35-80). Sempat dipikirkan untuk memberikan fludrocortisone atau prednisone untuk memperbaiki kondisi CSWS namun demikian sebelum diberikan, produksi urine membaik pada 12 jam terakhir hari ke-4 pascabedah ini sehingga menjadi $200-250 \mathrm{~mL} /$ jam pada awal hari ke-5 pascabedah, sehingga pemberiannya ditunda.

Pada hari ke-5 pascabedah kondisi pasien pasien bernapas spontan RR 16 kali per menit dengan $\mathrm{SpO}_{2}$ 98-99\% dengan udara bebas. Tekanan darah 112/78 (89) $\mathrm{mmHg}$, nadi 89 kali per menit. Kesadaran GCS E4V5M6, produksi urine 3 jam terakhir berkisar 200-250 mL/24 jam. Pada waktu ini didapatkan pula hasil pemeriksaan

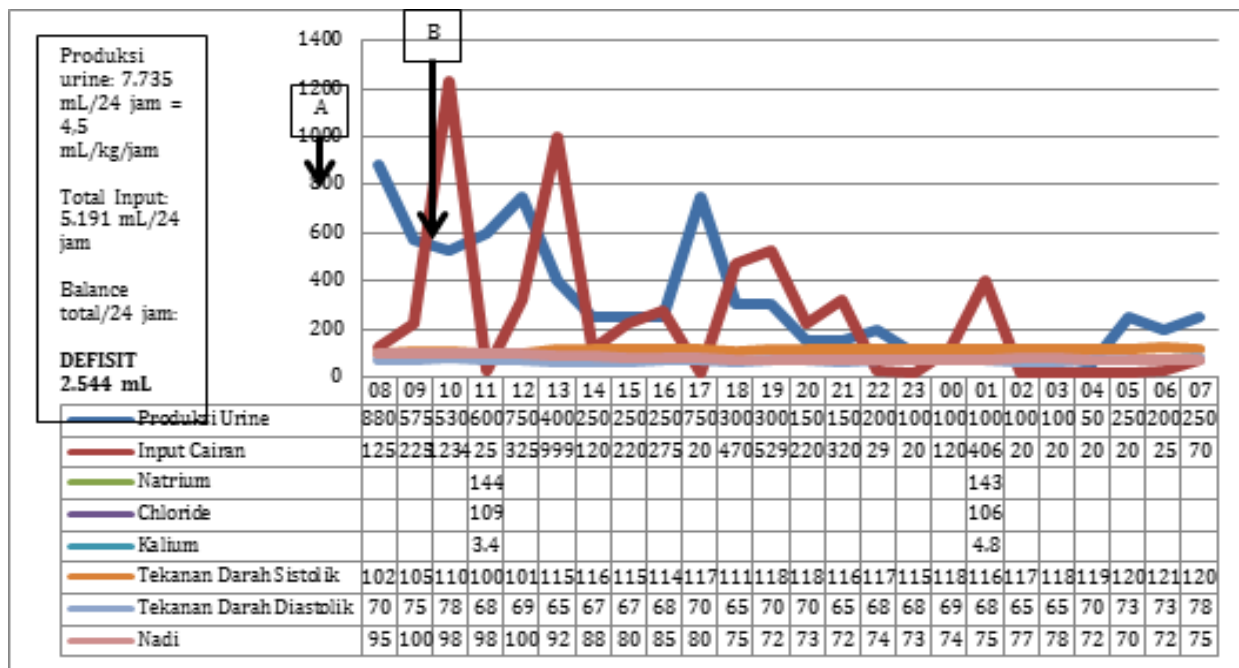

Grafik 4. Kondisi Pasien hari ke-4 Pascabedah 
elektrolit dari urine tampung 24 jam sebelumnya, yaitu: natrium: 381,75 (normal 30-300), chloride 508,76 (normal 85-170) dan kalium 38,16 (normal 35-80). Dari data ini disimpulkan pasien masih mengalami natriuresis walaupun sudah berkurang dari pemeriksaan sebelumnya. Dengan mempertimbangkan kada natrium dalam plasma yang masih normal, cenderung tinggi pada hari ini (143-144 mEq/L), pemberian fluhydrocortisone untuk tatalaksana CSWS ditunda dengan catatan produksi urine dan serum elektrolit tetap dipantau ketat. Pasien masih diberikan minirin per oral 0,1 mg tiap 8 jam, minum bebas tercatat dan infus Ringerfundin $500 \mathrm{~mL} / 24$ jam serta diobservasi tanda-tanda kenaikan intrakranial, tanda vital dan produksi urine. Pada hari kelima pasca bedah ini pasien dipindahkan ke ruangan perawatan biasa dengan catatan khusus waspadaterhadap DI dan CSWS.

\section{Pembahasan}

Diabetes insipidus (DI) merupakan gangguan keseimbangan cairan yang ditandai dengan ekskresi urin hipotonis melebihi $2 \mathrm{~mL} / \mathrm{kg}$ berat badan per jam.4 Tantangan diagnostik adalah dalam memastikan kondisi poliuria dan membedakan antara tiga proses utama yang mengarah pada urin yang encer dan banyak. Poliuria dapat terjadi karena gangguan pada salah satu dari tiga komponen kontrol fisiologis keseimbangan cairan yaitu: kurangnya sekresi vasopressin atau central diabetes insipidus (CDI) yang mencerminkan kerusakan hipotalamus atau hipofisis posterior, gangguan ginjal dalam pemekatan urine sebagai respons terhadap AVP (nephrogenic diabetes insipidus - NDI) dan penafsiran rasa haus yang berlebihan (primary polydipsia - PP). ${ }^{4}$

Sebagian besar CDI terjadi sekunder karena kondisi neurologis di antaranya craniopharyngioma, pascabedah adenoma dan tumor sekresi, idiopatik/autoimun, infiltrasi, tumor lain, vascular/COT dan apopleksi. ${ }^{4}$ Pasien ini mengalami DI kemungkinan sejak fase prabedah, ditandai dengan kondisi hipernatremia $154 \mathrm{mEq} / \mathrm{L}$ walaupun tidak ada data jumlah produksi urine. Hal ini cukup jarang mengingat posisi tumor berada di daerah pineal, namun melihat besarnya sistem ventrikel pada gambaran MRI kepala prabedah menunjukkan tingkat obstruksi aliran cairan cerebrospinal yang cukup berat. Kondisi ini menggambarkan tekanan intrakranial dan penekanan pada hipotalamus yang cukup berat dapat mendasari terjadinya DI sejak prabedah. Selain itu, jenis tumornya yaitu germ cell tumor merupakan tumor yang jarang terjadi dan secara khas menyerang pasien lakilaki pada dekade kedua kehidupan. ${ }^{5}$ Tumor ini paling sering terjadi pada kelenjar pineal dan regio suprasella6 dengan gejala khasnya adalah diabetes insipidus (DI), dengan ataupun tanpa defisit hipofisis lainnya, gangguan penglihatan, peningkatan TIK dan sindroma Parinaud. ${ }^{5}$ Tumor ini bersifat imunogenik dan menyebabkan respons imun yang kuat di sekitar tumor yang dapat mempengaruhi jaringan sehat yang di sekitarnya dan menyebabkan manifestasi hipofisitis sekunder. ${ }^{7}$

Hipofisitis merupakan kondisi yang jarang terjadi, ditandai dengan inflamasi pada kelenjar dan/atau batang hipofisis yang menyebabkan pembesaran hipofisis dengan atau tanpa hipopituitarisme.7 Selain itu, germinoma juga menyebabkan reaksi granulomatosa yang dapat pula menyebabkan terjadinya hipofisitis. ${ }^{8}$ Kondisi DI ini berlanjut sampai pasca bedah dengan kadar natrium serum tertinggi $173 \mathrm{mEq} / \mathrm{L}$ dan produksi urine terbanyak $10,5 \mathrm{~mL} / \mathrm{kg} / \mathrm{jam}$. Target pengelolaan DI dilakukan berdasarkan pemberian desmopressin ditambah dengan water intake yang akan menghasilkan produksi urine harian 1,5-2 liter. $^{9}$

Penanganan DI pada prinsipnya mencakup 3 hal, yaitu penggantuan defisitfree water dan pemberian defisit hormon dan terapi kondisi yang mendasari. ${ }^{4}$ AVP memiliki waktu paruh dalam plasma 5-10 menit, sehingga terlalu singkat untuk penggunaan secara klinis. dDAVP merupakan analog sintetik untuk reseptor V2 yang telah dimodifikasi dari AVP pada 2 hal; kelompok amino sistein telah dihilangkan untuk memperpanjang waktu paruh, sedangkan D-arginin diganti dengan L-arginin untuk menghilangkan efeknya terhadap tekanan 
darah. Obat ini tersedia dalam bentuk parenteral, oral dan nasal dengan dosis oral 100-400 mcg sedangkan dosis parenteral 1-4 mcg subkutan. Sediaan nasal memiliki onset yang lebih cepat namun efektivitasnya mungkin berkurang ketika ada inflamasi mukosa. ${ }^{4}$ Sebagian besar pasien lebih memilih sediaan oral karena alasan kenyamanan. Umumnya DI akut pascabedah bersifat sementara dan memberikan respons baik dengan pemberian dosis tunggal dDAVP parenteral. ${ }^{10}$ Pemberian lebih lanjut mungkin diperlukan bila polyuria kembali terjadi. Terkadang terjadi respons trifasik di mana DI awal diikuti dengan kondisi antidiuresis dan hiponatemia, yang kemudian kembali ke kondisi DI permanen. Oleh karenanya, mengingat DI sering bersifat sementara, pemberian dDAVP secara reguler hanya dilakukan bila poliuria menetap lebih dari 48 jam, dengan pemantauan kadar natrium plasma dan volume urin dilakukan terus menerus. ${ }^{11}$

Pada pasien ini, DI yang terjadi pascabedah dini berespons sangat baik dengan pemberian Desmopressine per oral $0,1 \mathrm{mg}$ tiap 8 jam dan produksi urine menurun hanya dilakukan pada 24 jam pertama pasca bedah sehingga kondisi DI kembali melanda pasien dan ditumpangi dengan CSWS yang makin memperbanyak produksi urine yang keluar bersama dengan natrium. Strategi penggantian cairan pada pasien ini berjalan cukup baik. Hal ini tidak lepas dari peran besar pasien sendiri yang memungkinkan untuk minum air putih per oral dengan cukup banyak, selain dibantu dengan pemberian cairan D5 (free water) melalui infus. Selain itu, pemantauan keseimbangan cairan tiap 3 jam, gula darah tiap 3 jam serta serum elektrolit tiap 6 jam (pada fase akut) memungkinkan pasien masih dalam batas kecukupan cairan yang tidak banyak tertinggal sehingga kadar natrium tidak makin meningkat. Hipernatremia yang berlebihan akan menyebabkan osmolalitas serum pasien melonjak tinggi dan hal ini berpengaruh terhadap terjadinya cedera otak sekunder. Pemberian D5 melalui infus juga berisiko meningkatkan kadar gula darah sehingga beban osmolalitas plasma pun dapat meningkat. Dengan pemantauan ketat maka status volume dan osmolalitas pasien dapat terus berada dalam koridor aman sehingga tidak terjadi cedera otak sekunder. Pemberian cairan pada pasien DI dapat pula menggunakan panduan berat badan. Pada pasien yang DI adipsik, pemberian cairan dilakukan dengan memotivasi pasien untuk minum air putih setidaknya $2 \mathrm{~L}$ per hari, sekalipun angka ini tidak pasti, bergantung pada luas permukaan tubuh, iklim sekitar, aktivitas fisik seseorang dan beberapa faktor lainnya. Selain itu pemberian cairan dapat pula dipantau berdasarkan berat badan pasien saat kondisi pasien eunatremia. ${ }^{12}$ Secara praktis, pasien dapat diberikan tambahan $0,5 \mathrm{~L}$ air bila berat badannya kurang $0,5 \mathrm{~kg}$ dibandingkan berat badan pada saat kondisi pasien eunatremia.

Namun demikian, setidaknya ada 2 hal yang dapat dilakukan lebih baik dalam perawatan pasien ini. Hal pertama adalah, dosis desmopressin yang diberikan masih dapat dioptimalkan. Besarnya dosis desmopressin (dDAVP) yang diberikan bergantung pada derajad defisiensi AVP. Pada pasien dengan DI ringan, dosis awal 100-200 mcg per oral pada malam hari cukup untuk mengendalikan nocturia. ${ }^{4}$ Dosis ini dapat dititrasi sampai dengan gejala terkontrol bahkan sampai dengan 200 mcg dua sampai tiga kali sehari pada DI yang lebih berat. ${ }^{4}$ Pada pasien ini pemberian desmopressin dilakukan sampai dengan $0,1 \mathrm{mg}$ $(100 \mathrm{mcg})$ tiap 8 jam, itu pun setelah 24 jam pertama pasca bedah, pemberiannya dihentikan. Seandainya pemberiannya diteruskan sampai dengan 48 jam pertama pasca bedah dan dengan dosis yang lebih besar, baru kemudian dititrasi sesuai kondisi klinisnya, maka pasien pasien mungkin tidak jatuh pada DI yang berat sampai dengan produksi urine 18 liter per hari dan lama perawatan di ICU dan rumah sakit juga akan lebih pendek.

Hal kedua yang mungkin bisa dilakukan adalah mencari penyebab DI sebenarnya. Tumor pineal sangat jarang menyebabkan DI. Pada pasien ini, diduga penyebab DI karena penekanan pada hypothalamus akibat obstruksi aliran cairan serebrospinal atau terjadinya hipofisitis akibat sifat dari germ cell tumor yang dapat memicu respons imun yang meluber ke jaringan sehat sekitar, termasuk hipofisis. Dengan dilakukan 
pemasangan EVD pada pasien ini, lambat laun penekanan pada hypothalamus akibat hidrosefalus akan berkurang, sehingga kondisi DI akan membaik. Sebaliknya, apabila penyebabnya adalah hipofisitis akibat sifat tumor, maka setelah pembedahan, pasien mungkin masih harus menjalani kemoterapi dan atau radioterapi, karena tumor yang melekat pada mesencephalon tidak diambil, sehingga masih mungkin menyebabkan respons imun ke jaringan sekitarnya dan terus menyebabkan DI pada pasien ini. Pengelolan hipofisitis memang masih kontroversial. Pada beberapa kasus, sembuh spontan pernah dilaporkan. Pemberian glukokortikoid telah menunjukkan kembalinya fungsi hipofisis dan pengerutan massa hipofisis tetapi steroid juga pernah dilaporkan gagal mengatasi kondisi ini. Oleh karenanya terapi lain seperti azathioprine, MTX, rituximab dan radiasi diberikan pada pasien-pasien yang refrakter terhadap steroid. ${ }^{13}$ Cerebral salt wasting syndrome (CSWS) terjadi sekunder dari penyakit sistem saraf pusat (SSP). Namun demikian, mekanisme yang mendasari sebenarnya belum terlalu jelas.

Beberapa hipotesis menyatakan beberapa kondisi patofisiologis yang mungkin terlibat di antaranya sistem renin angiotensin aldosterone, SSP, peptide natriuretic dan sebagainya. ${ }^{14}$ CSWS berlangsung sementara dan pasien berangsur kembali ke normal setelah 3-4 minggu. Pada CSWS terjadi pembuangan natrium dalam urine dan air juga ikut terbawa. Oleh karenanya manifestasi klinisnya adalah hiponatremia hipovolemia dan natriuresis. Kunci terapi CSWS adalah penggantian air dan natrium yang hilang melalui urine. Selain itu pemberian fluhydrocortisone dapat membantu memperbaiki keseimbangan negatif natrium dengan mengingkatkan reabsorpsi natrium dan tubulus renalis. ${ }^{14}$ Data yang mendukung CSWS pada pasien ini adalah jumlah urine yang banyak dan natriuresis, sedangkan kadar natrium dalam plasma termasuk hipernatremia. Hal ini mungkin karena CSWS yang terjadi bersamaan dengan DI. Pada pasien ini penggantian cairan berupa minum air putih per oral dan D5 melalui infus disertai dengan observasi ketat kadar elektrolit dan glukosa dalam plasma. Terapi berupa fluhydrocortisone yang dapat meningkatkan reabsorpsi natrium tidak diberikan pada pasien ini dengan pertimbangan kondisi pasien masih dalam kondisi hipernatremia ringan sampai dengan akhir perawatan di ICU. Pasien perlu terus dipantau status volume dan kadar elektrolit plasma terkait kombinasi patofisiologi yang terjadi pada pasien ini yaitu DI dan CSWS.

Pneumocephalus bukan merupakan fenomena yang jarang terjadi setelah fraktur hidung dan sinus paranasalis. Mekanisme masuknya udara dapat dijelaskan dengan 'efek botol terbalik' di mana kebocoran cairan serebrospinal dari defek dura menyebabkan udara terhisap ke dalam ruang subdural, mirip dengan fenomena yang terlihat setelah membalik botol yang terisi. ${ }^{15}$ Lebih jauh lagi, setelah bersin atau batuk, tekanan yang besar akan memaksa udara masuk ke dalam kalvaria, yang tidak dapat keluar melalui efek ball-valve ${ }^{16}$ dari flap dura pada tempat robekan. Ketika tekanan gas subdural intrakranial meningkat (tension pneumocephalus), dapat terjadi efek massa pada otak, terutama pada daerah frontal karena lokasinya yang independen. ${ }^{15}$ Bila tekanan gas ini melampaui tekanan permukaan cairan serebrospinal (hampir sama dengan air), hal ini menyebabkan pemisahan aspek medial lobus frontalis, yang biasanya tampak berdempetan, dan pelebaran fisura interhemisfer. Efek massa pada lobus frontalis ini dengan pemisahan kutub frontal disebut "Mount Fuji sign" karena kemiripannya dengan gunung berapi yang terkenal di Jepang. ${ }^{15}$

Pneumocephalus sendiri dapat diterapi dengan meningkatkan oksigen inspirasi ${ }^{17}$ melalui efek gas ketiga, dengan infus lumbar pascabedah atau posisi Trendelenburg dengan menurunkan kepala 30 derajad horizontal. ${ }^{18}$ Dengan terapi ini dalam 1 minggu pascabedah, volume pneumocephalus menurun sekitar $70 \%$ secara spontan dan. 18 Apabila kondisi ini tidak diterapi maka dapat berakibat kejang, kerusakan struktur SSP yang signifikan, kerusakan otak permanen bahkan kematian. ${ }^{16}$ Tindakan pembedahan dekompresi perlu dilakukan untuk mencegah terjadinya herniasi otak dan lebih parah lagi, kematian. ${ }^{16}$

Selain itu pada pasien ini juga terjadi 
pneumoventrikel pascabedah, kemungkinan karena penurunan tekanan akibat cairan serebrospinal terdrainage melalui EVD atau karena ada defek tulang dan dura pascabedah. Kondisi kesadaran pasien yang baik mungkin menjadi pertimbangan ahli bedah tidak melakukan tindakan bedah apapun terkait kondisi pneumocephalus dan pneumoventrikel ini. Beberapa hal baik yang telah dilakukan selama penanganan ketidakseimbangan natrium dan air pada pasien ini di antaranya adalah pemantauan ketat kondisi pasien, di antaranya produksi urine tiap jam, keseimbangan cairan tiap 3 jam, sehingga pasien tetap dalam koridor status volume yang aman, selain itu pemantauan kadar natrium dalam plasma yang dilakukan secara berkala sehingga meskipun pasien masih dalam kondisi hipernatremia ringan $(145-148 \mathrm{mEq} / \mathrm{L})$ pasien tetap dalam kondisi cukup baik dengan kondisi kesadaran normal.

\section{Simpulan}

Pengelolaan diabetes insipidus pascabedah eksisi tumor pineal memerlukan pengertian menyeluruh mengenai patofisiologi kelainan intrakranial dan efeknya pada keseimbangan cairan dan elektrolit. Lebih jauh lagi pada kasus ini selain diabetes insipidus, pasien juga mengalami cerebral salt wasting syndrome dan tension pneumocephalus. Pengelolaan pasien ini memerlukan pemantauan ketat keseimbangan cairan, elektrolit dan gula darah serta pemberian dosis desmopressin yang tepat. Pada akhirnya meskipun ada beberapa hal yang dapat dilakukan lebih baik dalam perawatan pasien ini, luaran pasien cukup baik dengan kondisi diabetes insipidus yang terkendali.

\section{Daftar Pustaka}

1. Matta BF, Menon DK, Smith M. Core topics in neuroanaethesia and neurointensive care. Cambridge University Press. United States of America; 2011: 281-99.

2. Laksono BH, Oetoro BJ, Rahardjo S, Saleh SC. Gangguan natrium pada pasien bedah saraf. JNI 2014; 3(1): 48-57.
3. Grant P, Whitelaw B, Barazi S, Aylwin S. Salt and water balance following pituitary surgery. European Society of Endocrinology 2012;11(0892):1-22.

4. Garrahy A, Moran C, Thompson CJ. Diagnosis and management of central diabetes insipidus in adults. Clin Endocrin 2019; 90: 23-30.

5. Dias D, Vilar H, Passos J, Leite V. Central diabetes insipidus caused by pituitary stalk germinoma resembling infundibuloneurohypophysitis. BMJ Case Rep 2020; 13:e234724.

6. Osorio DS, Allen JC. Management of CNS germinoma. CNS Oncol 2015; 4: 273-9.

7. Pal R, Rai A, Vaiphei K, Gangadhar P, Gupta $\mathrm{P}$, Kumar $\mathrm{K}$, et al. Intracranial germinoma masquerading as secondary granulomatous hypophysitis: A case report and review of literature. Neuroendocrinology 2020; 110(5): $422-9$.

8. Jinkala S, Muthalagan E, Badhe B. Granulomatous response in intracranial germinomas: Diagnostic problems. Int J Appl Basic Med Res 2018; 8: 51.

9. Ball SG, Vaidja B, Baylis PH. Hypothalamic adipsic syndrome:diagnosis and management. Clin Endocrinol 1997; 47: 405-9.

10. Hannon MJ, Finucane FM, Sherlock M, Agha A, Thompson CJ. Clinical review: disorders of water homeostasis in neurosurgical patients. J Clin Endocrinol Metab 2012; 97(5): 1423-33.

11. Garrahy A, Sherlock M, Thompson CJ. Management of endocrinde disease: Neuroendocrine surveillance and management of neurosurgical patients. Eur J Endocrinol 2017; 176(5): R217-33.

12. Cuesta M, Hannon MJ, Thompson CJ. Adipsic diabetes insipidus in adult patients. 
Pituitary $2017 ; 20: 372-80$.

13. $\mathrm{Xu} \mathrm{C}$, Ricciuti A, Caturegli $\mathrm{P}$, Keene CD, Kargi AY. Autoimmune lymphocytic hypophisitis in association with autoimmune eye disease and sequential treatment with infliximab and rituximab. Pituitary 2015; 18 : $441-7$.

14. Junhai Z, Jing Y, Li L. Cerebral Salt-wasting Syndrome in a Critically Ill Patient: An Easily Neglected Syndrome in Intensive Care Unit (ICU). J NATL MED ASSOC 2020 vol. 112 (3): 258-61.

15. Ranwaka AA, Mehta AS. Tension pneumocephalus after frontal sinus fracture: Mount Fuji Sign. Int J Otorhinolaryngol Clin 2017; 9(2): 79-80.
16. Lasoff DR, Wardi G, Sloane C. Mount Fuji Sgn: Tension Pneumocephalus in the Emergency Department. J Emerg Med 2019; $\mathrm{x}(\mathrm{x}): 1-2$.

17. Huang GH, Li XC, Ren L, Dai RX, Sun ZL, Jiang XF, Feng DF. Take it seriously or not: postoperative pneumocephalus in CSDH patients? Br J Neurosurg 2020, DOI: 10.1080/02688697.2020.1729343.

18. Siegel JL, Hampton K, Rabinstein AA, Mclaughlin D, Diaz-Gomez JL. Oxyge therapy with high flow-nasal cannula as an effective treatment for prerioperative pneumocephalus: case illustrations and pathophysoiological review. Neurocrit Care 2017: 29: 1-8. 